\title{
Global projections for anthropogenic reactive nitrogen emissions to the atmosphere: an assessment of scenarios in the scientific literature

\author{
Detlef $P$ van Vuuren ${ }^{1,2}$, Lex F Bouwman ${ }^{1,2}$, Steven $\mathrm{J} \mathrm{Smith}^{3}$ and \\ Frank Dentener ${ }^{4}$
}

\begin{abstract}
Most long-term scenarios of global reactive nitrogen (Nr) emissions to the atmosphere are produced by Integrated Assessment Models in the context of climate change assessments. These scenarios indicate that these global $\mathrm{Nr}$ emissions are likely to increase in the next decades, followed by a stabilization or decline. Crucial factors for future $\mathrm{Nr}$ emissions are the development of the underlying drivers (especially fertilizer use, animal husbandry, transport, power generation and fires), air pollution control and climate policies. The new scenarios made for climate change research and assessment, the Representative Concentration Pathways $\mathrm{RCPs}$, cover a smaller range of possible $\mathrm{Nr}$ emission projections than the literature, as they all assume progressive air pollution control. A more focused development of scenarios for air pollution may be needed to improve both the relevance and quality of the scenarios for research and assessment of air pollution (and possibly short term climate change).
\end{abstract}

\begin{abstract}
Addresses
${ }^{1}$ PBL Netherlands Environmental Assessment Agency, Bilthoven, The Netherlands

${ }^{2}$ Utrecht University, Faculty of Geosciences, Utrecht, The Netherlands ${ }^{3}$ Joint Global Change Research Institute, Pacific Northwest National Laboratory, College Park, MD, USA

${ }^{4}$ European Commission, Joint Research Centre, ISPRA, Climate Change Unit, Italy
\end{abstract}

Corresponding author: Vuuren, Detlef P van (detlef.vanvuuren@pbl.nl)

Current Opinion in Environmental Sustainability 2011, 3:359-369

This review comes from a themed issue on

Carbon and nitrogen cycles

Edited by Carolien Kroeze and Lex Bouwman

Received 15 May 2011; Accepted 20 August 2011

$1877-3435 / \$$ - see front matter

(C) 2011 Elsevier B.V. All rights reserved.

DOI 10.1016/j.cosust.2011.08.014

\section{Introduction}

Disturbance of the nitrogen $(\mathrm{N})$ cycle has been identified as a key sustainability problem in several international environmental assessments [1-4]. The most important reactive nitrogen substances emitted into the atmosphere by human activities are nitrous oxide $\left(\mathrm{N}_{2} \mathrm{O}\right)$, nitric oxides ( $\mathrm{NO}$ and $\mathrm{NO}_{2}$ together denoted as $\mathrm{NO}_{x}$ ) and ammonia $\left(\mathrm{NH}_{3}\right)$ (we will refer to these together as $\mathrm{Nr}$ gases).
Nitrogen input to surface and subsurface waters are an additional form of disturbance of the N-cycle, but this paper will focus on atmospheric emissions. An important consequence of atmospheric emissions is the increased deposition of nitrogen oxides, ammonia and ammonium species, leading to several environmental effects. This includes 1) acidification, 2) excess $\mathrm{N}$ loading in ecosystems (eutrophication) leading to decreased biodiversity, 3) direct toxicity, 4) nitrate leaching, and 5) increased susceptibility to secondary stress factors and ecosystem diversity $\left[5,6,7^{\bullet}, 8^{\bullet \bullet}, 9^{\bullet}\right]$.

The contribution of increased $\mathrm{N}$ deposition to acidification and eutrophication has been analysed at a global scale $\left[7^{\bullet}, 10\right]$ showing that both acidification and eutrophication can be expected to expand outside industrialized countries. Excess $\mathrm{Nr}$ loading is expected to lead to subsequent shifts in plant species composition towards nitrophilic species [11-13], which in turn, may lead to biodiversity loss, and in aquatic systems to algal blooms and decreased water quality. Increased $\mathrm{Nr}$ deposition may also lead to increased carbon storage $\left[9^{\bullet}, 14,15\right]$ and thus affecting the carbon cycle. Finally, $\mathrm{Nr}$ gas emissions can play a role in the greenhouse effect. $\mathrm{N}_{2} \mathrm{O}$ emission contribute to about $6 \%$ of global greenhouse gas emissions [16], while $\mathrm{Nr}$ emissions can also affect tropospheric ozone chemistry and aerosol formation, which both play an important role in climate change forcing [17].

Given the importance of $\mathrm{Nr}$ gas species for these environmental effects, it is important to assess how mankind will influence the global $\mathrm{N}$ cycle in the future. Many different processes are responsible for $\mathrm{Nr}$ gas emissions. Fossil fuel combustion, biomass burning, lightning and microbiological processes in soils are the major processes involved in the production of $\mathrm{NO}_{x}$ [18] and $\mathrm{N}_{2} \mathrm{O}$ [19]. $\mathrm{NH}_{3}$ stems mostly from volatilization from animal waste and synthetic fertilizers, biomass burning, losses from oceans and soils under natural vegetation, emissions from waste, industrial processes and traffic [20]. As discussed further in this article, many of the economic activities that drive $\mathrm{Nr}$ emissions are expected to increase over time. At the same time, increasing environmental awareness and improvements in technology could lead to emission reduction. While for greenhouse gas emission scenarios (most importantly $\mathrm{CO}_{2}$ ) regularly model comparisons are organised [21-23], similar systematic comparisons for future $\mathrm{N}$ emissions do not exist (and also the number 
of projections is considerably less). Recently, Granier et al. [24] compared different emission inventories and showed considerable uncertainties even with respect our understanding of historic and current emissions.

In this paper, we present a brief assessment based on literature on expected future changes in reactive $\mathrm{N}$ gas emissions under different scenario assumptions. We will focus primarily at the global level. It should be noted, however, that many more projections exists at the regional as part of initiatives to improve regional environmental quality. At the global level, many of the scenarios evaluated here were performed in the context of assessment of greenhouse gas emissions (as climate models use reactive $\mathrm{N}$ gas emissions as input data). In Section 'Scenario analysis', we first discuss some of the key concepts in the scenario literature. In Section 'Projections of atmospheric nitrogen emissions', we look into the projections for $\mathrm{NO}_{x}, \mathrm{~N}_{2} \mathrm{O}$ and $\mathrm{NH}_{3}$. Finally, in Section 'Conclusions' we draw the conclusions of this assessment.

\section{Scenario analysis}

Integrated assessment models (IAM) are often used to develop global emission scenarios. Integrated assessment models looking specifically at air pollution often have a regional focus, such as the RAINS for Europe $[25,26]$ and the RAINS Asia model for South and East Asia [27,28]. The RAINS model has more recently been expanded into the GAINS model expand to joint strategies for managing air pollution and greenhouse gas emissions [29,30]. Integrated Assessment models of climate change often focus at the global scale. Their scenarios often also include $\mathrm{Nr}$ gas emissions. Some of these IAMs are also applied to study environmental problems in a more general context, such as for the Global Environmental Outlook and the Millennium Ecosystem Assessment [1-3].

Future developments in $\mathrm{Nr}$ gas emissions are estimated on the basis of projected changes in relevant economic activities and the emissions per unit of these activities. This can be done in different ways. The most common approach is to calculate emission on the basis of the product of economic activity levels and emission factor (Emission$\mathrm{s}=$ Activity $\times$ emission_factor. The latter equals the emission rate per unit of the activity. Such emission factors can be estimated on the basis of detailed representations of abatement technologies ('technology basis') combined with rules on the desired environmental quality or maximum expenditures [26,31]. Emissions factors can, however, also be single values as a function of time, that follow certain exogenously prescribed or endogenously derived trends representative for the particular sector or region ('representative emission factors'). Both the simple and more complex derived emission factors can be determined on the basis of existing and future policies in different parts of the worlds (such as the Current Legislation, CLE) scenarios of Cofala $e t$ al. [30] or the use of empirically observed trends such as the Environmental Kuznets Curve (EKC) [32-35]. The EKC suggests that, starting from lowincome levels, emissions will originally increase with increasing income but at some point will peak and subsequently decline. The latter is driven not only by increasingly tight environmental policies, but also by shifts towards industries with lower emissions (include the service sector) and improved technology. There is, however, a fundamental debate whether the EKC is valid and whether it can be extrapolated to the future [32,36]. Usually emission factors will change over time to reflect changes in technology, policy and economic activity levels. As discussed in Section 'Current emissions uncertainty', there is a wide set of emission inventories that contain information on current emissions factors. For $\mathrm{Nr}$ gas emissions from soils where biological processes (nitrification and denitrification in the case of $\mathrm{N}_{2} \mathrm{O}$ and $\mathrm{NO}$ ) or physical-chemical processes $\left(\mathrm{NH}_{3}\right.$ volatilization) are responsible for the production, consumption and emission, often more complex approaches are used. Such approaches range from statistical models $[37,38]$ to more complex mechanistic models $[39,40]$.

The uncertainties in the processes that determine future emissions as discussed above (economic activity levels, technological development, future legislation, and its effective implementation, chemical and physical interactions) contribute to the uncertainty in future emissions. In most cases, $\mathrm{Nr}$ gas emissions do not occur as a fixed fraction of some input or activity level (as is the case for $\mathrm{CO}_{2}$ ), which leads to a larger amount of uncertainty in these emissions. In the case of combustion emissions, $\mathrm{Nr}$ gas emissions depend on combustion temperature and other characteristics of the technology considered. Emissions from biological processes are extremely variable in space and time, and depend on temperature, soil properties, and soil moisture.

When comparing scenarios, uncertainty becomes apparent in different ways. First of all, different models and studies lead to different estimates of future emissions. Secondly, even within one study a model may be used to develop widely diverging scenarios based on different assumptions on the type of future scenario [30,41] or the introduction of climate policy [42]. In the discussion in the remainder of this article, the spread in emissions projections (indicated by the 10th-90th percentile of their range) is loosely interpreted as an indication of uncertainty in future emissions levels. It is useful to keep in mind, however, that future emissions may well fall outside the range of scenario projections, particularly since many of the scenarios examined were not constructed with a principal focus on $\mathrm{Nr}$ gas emissions. It goes beyond the scope of this brief assessment to discuss the development of individual emission factors in detail. In order to better understand the differences in the projections, it would be useful to do so in a more detailed paper also in relation to the emission factors 
used in inventories of current emissions (see also Section 'Current emissions uncertainty').

For the purpose of this assessment, we have compared global scenarios that include a description of long-term (i.e. at least several decades) trends in emissions of $\mathrm{NO}_{x}$, $\mathrm{N}_{2} \mathrm{O}$ and $\mathrm{NH}_{3}$. Studies included within this category are: 1) some of the scenarios that are developed to study air pollution, such as $[30,43], 2)$ the IPCC-SRES scenarios $[44], 3)$ the set scenarios from a wide range of models used by Van Vuuren $e t$ al. $\left[45^{\circ}\right]$ to project 21st century climate change (based on the EMF-21 scenarios [22]), 4) the scenarios developed for EMF-22 [21] and 5) the Representative Concentration Pathways recently published to examine the implications of a range of future climate forcings $\left[46,47^{\circ \bullet}\right]$. We also discuss scenarios developed to explicitly assess different futures with respect to global environmental change, such as the scenarios related to the $\mathrm{N}$ cycling as developed for the Millennium Ecosystem Assessment $\left[41,48,49^{\circ}, 50^{\circ}\right]$ and the International Assessment of Agricultural Knowledge, Science and Technology for Development (IAASTD) $\left[3,50^{\circ}\right]$. The Integrated Model to Assess the Global Environment (IMAGE) model [51] has been used to develop several sets of such scenarios in different assessments. We acknowledge that a large number of scenarios have been developed for regional assessments of the impact of $\mathrm{Nr}$ gas emissions $[28,52]$. These scenarios, however, fall outside the scope of this assessment.

\section{Projections of atmospheric nitrogen emissions \\ Current emissions uncertainty}

The emission scenarios examined here, are generally based on emission inventories for a specific base year as a starting point. There is range of different inventories that provide emission data on a global level. Important available inventories include the EDGAR database [53], the database underlying the RAINS/GAINS system (see earlier references), the RETRO database [54] and the ACCMIP database. The latter has actually been constructed on the basis of combination and harmonization of published and publicly available datasets [24,55 ${ }^{\circ}$. A recent overview of available inventories was conducted by Granier et al. [24]. This overview shows that, in general, there are large differences across the databases, on the global scale but even more so on the regional scale (see also [56]). Among the different $\mathrm{Nr}$ gas, there are also clear differences in the degree of consensus among historical emission and inventories. This uncertainty in the base-year and historical emissions is a major source of uncertainty in future projections.

The global $\mathrm{N}_{2} \mathrm{O}$ emission budget is reasonably wellconstrained by available knowledge on the most important sink, $\mathrm{N}_{2} \mathrm{O}$ destruction in the atmosphere. Even with this overall constraint, the partitioning between anthropogenic and natural $\mathrm{N}_{2} \mathrm{O}$ emissions is difficult to quantify. There are few such overall observationally based constraints for $\mathrm{NO}_{x}$ or $\mathrm{NH}_{3}$ emissions. Yet, Granier et al. [57] conclude that "there is a rather good consensus on the $\mathrm{NO}_{x}$ global emissions". For the year 1980, for instance, it was found that the difference between three databases was equal to $13 \%$, while for the year 2000 , the five inventories compared show a maximum difference around $15-20 \%$, respectively.

Most of the inventories do not include explicit uncertainty estimates [24]. Schöpp et al. [58] estimated a 10-20\% uncertainty at the country level for $1990 \mathrm{NO}_{x}$ emissions in Europe, and slightly higher values for $\mathrm{NO}_{x}$ emissions from shipping in European waters, and $\mathrm{NH}_{3}$ emissions in general. Beusen et al. [59] estimated a $20 \%$ uncertainty in $\mathrm{NH}_{3}$ emissions from agricultural production, where uncertainty in individual $\mathrm{NH}_{3}$ sources (such as animal manure storage, spreading, grazing animals) may be much larger. The foundation of these uncertainty assessments is expert judgment, since measurement data necessary for a more rigorous approach is generally not available (and real uncertainty might even be larger).

The comparison of existing inventories suggests that the uncertainty might be considerably higher [24]. One factor that reduces uncertainty for emissions such as $\mathrm{NO}_{x}$ is cancellation across sectors. Errors in emissions coefficients for one sector are generally expected to be uncorrelated with errors in another sector, which reduces the net uncertainty. Overall, the uncertainty is expected to be larger in countries without well-developed infrastructure for emissions inventory development (in some cases, there might be factor of 2 differences between observations and model calculations).

A detailed comparison of emission factors in the various inventories and future scenarios is currently. Although this exercise is far from straightforward (e.g. owing to different sectoral definitions), it would be of value in understanding differences between various studies and, potentially, reducing uncertainty

\section{Projections for $\mathrm{NO}_{x}$}

A recent estimate of global anthropogenic $\mathrm{NO}_{x}$ emissions in the year 2000 amounted to nearly $40 \mathrm{Tg} \mathrm{N} \mathrm{yr}^{-1}\left[55^{\circ}\right]$. These emissions rapidly increased during the 20th century. The major part of these emissions (more than $30 \mathrm{Tg} \mathrm{yr}^{-1}$ ) originate from fossil fuel combustion, that is, road transport $(10 \mathrm{Tg})$, shipping and aviation $(6 \mathrm{Tg})$, the energy sector $(7.5 \mathrm{Tg})$, industry $(4.5 \mathrm{Tg})$ and buildings $(3 \mathrm{Tg})$. In addition, around $6 \mathrm{Tg} \mathrm{N} \mathrm{yr}^{-1}$ originates from biomass burning.

In the future, the most important sources, that is, transport and power production, are expected to grow rapidly in terms of energy consumption, in particular in developing 
countries. As a result, it is likely that these sectors will continue to dominate $\mathrm{NO}_{x}$ emissions. Typically, global energy demand by the transport sector is projected to grow by about $60-260 \%$ across a range of scenarios in the 2000-2050 period and expected to grow even more in the second half of the century $[34,42,60]$. For electricity production, scenarios show even faster increases: 200$300 \%$ in the $2000-2050$ period and possibly at a similar rate after 2050.

While the growth in these activity levels would lead to higher $\mathrm{NO}_{x}$ emissions, other factors could partly offset this such as the increasing stringency of $\mathrm{NO}_{x}$ air pollution control policies in different parts of the world and the fuel and technology choices (including efficiency) in the energy system (which could be influenced by climate policy, see below).

Future emission scenarios span a wide range from about 10 up to $100 \mathrm{Tg} \mathrm{N} \mathrm{yr}^{-1}$ and higher (Figure 1). According to Cofala et al. [30] the current legislation scenario would more-or-less stabilize global emissions in the next decades, while the maximum feasible reductions would result in a $60 \%$ reduction compared to 2000 . The IPCC-SRES A2 scenario published in 2000 [44] and a more recently published scenario by MIT [61] are at the high end of the range $\left(70 \mathrm{Tg} \mathrm{N} \mathrm{yr}^{-1}\right.$ in 2050 and above $100 \mathrm{Tg} \mathrm{N} \mathrm{yr}^{-1}$ in 2100). Most scenarios, however, show emissions to be in the order of $30-50 \mathrm{Tg} \mathrm{N} \mathrm{yr}^{-1}$ in 2050 and $20-50 \mathrm{Tg} \mathrm{N} \mathrm{yr}^{-1}$ in 2100 - or in other words, a $10-20 \%$ increase in the next few decades followed by a stabilization of emissions (without climate policy) or a modest decline (with climate policy). This implies that the range is still rather comparable as the range considered some years ago, such as by Unger et al. [62] (31-56 $\mathrm{Tg} \mathrm{N} \mathrm{yr}^{-1}$ in 2030).

Emissions are expected to grow much less than the corresponding economic drivers, as discussed above. This is the result of considerable decreases in future emission factors in most scenarios. It can be easily derived that, at the global level, for median scenarios the 'aggregated emission factors' (as a result of air pollution control and technology development) decrease by around $60 \%$ in 2050 and $80 \%$ in 2100 . Frozen emission factors, that is, constant at 2000 level, would result in annual emissions in the order of $120 \mathrm{Tg} \mathrm{N}$ and $200 \mathrm{Tg} \mathrm{N}$ in 2050 and 2100, respectively. As the more detailed calculations underlying the Cofala projections indicate, such reductions are technically possible.

Comparison of the left-hand and right-hand side of Figure 1 shows that also future climate policy is likely to reduce $\mathrm{NO}_{x}$ emissions, given the fact that the systemic changes to reduce $\mathrm{CO}_{2}$ emissions introduced in the energy system in response to climate policy, will also reduce $\mathrm{NO}_{x}$ emissions. Data from a set of scenarios from 6 different models suggest that on average a $10 \%$ reduction in $\mathrm{CO}_{2}$ emissions leads to a $5 \%$ reduction in $\mathrm{NO}_{x}$ emissions (Figure 2). The available data also suggest that this 'co-benefit' ratio is somewhat reduced in the long-term (less $\mathrm{NO}_{x}$ reduction for a given reduction of $\mathrm{CO}_{2}$ ).

\section{Figure 1}
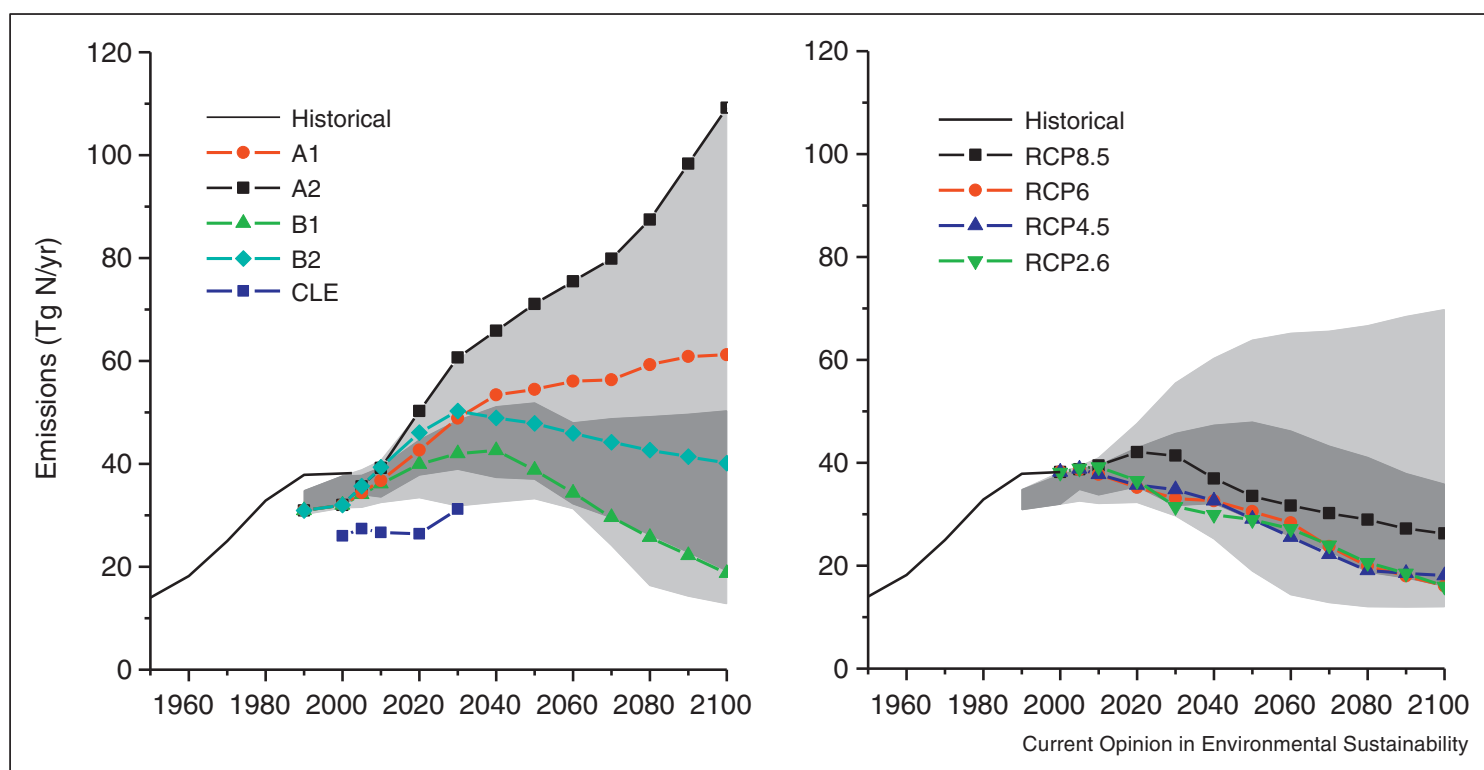

Future $\mathrm{NO}_{x}$ emissions according to various scenarios (light grey area covers the 10-90th percentile; dark grey area the 25-75th percentile). The right hand panel only includes scenarios without climate policy (22 scenarios); the left hand panel includes the full set of scenarios (with and without climate policy) (40 scenarios). The graph also shows the scenarios of the IPCC-SRES set [37], the IIASA-CLE scenario (both sets do not include climate policy) [26] and the RCPs (including climate policy) [40]. 
Figure 2

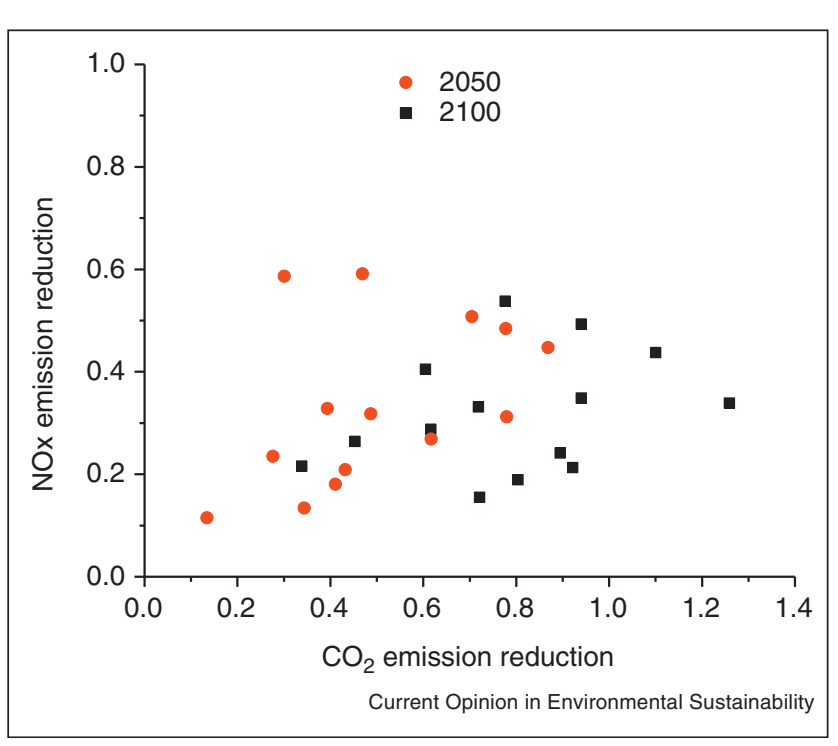

Relationship between $\mathrm{CO}_{2}$ and $\mathrm{NO}_{x}$ emission reduction (fraction of baseline emissions) as a result of the introduction of climate policy in the scenario set used by van Vuuren et al. [38], created by 6 different models. The figure indicates that in all models, climate policy alone also leads to significant $\mathrm{NO}_{x}$ emission reduction (although the exact relationship differs per model).

Typically, scenarios from literature portray very clear shifts in emissions from OECD countries to Asia and to a lesser degree other developing regions, as illustrated in Figure 3 for one scenario. Similar trends are observed in more detailed regional projections, such as for Europe and
Asia [28,30,63,64]. In terms of sectors, emissions mostly increase in the energy sector (power generation). Transport emissions remain more-or-less stable as a result of opposing trends in activity levels and emission factors, following a fast-global technology shift, imposed by regional emission standards such as EURO2-to-EURO6.

\section{Projections for $\mathrm{N}_{2} \mathrm{O}$}

Estimates of anthropogenic $\mathrm{N}_{2} \mathrm{O}$ emissions in 2000 are of the order of $7.5 \mathrm{Tg} \mathrm{N} \mathrm{yr}^{-1}\left[55^{\circ}\right]$. The bulk of these emissions stem from agricultural activities ( $7 \mathrm{Tg} \mathrm{N} \mathrm{yr}^{-1}$ ), 1), especially direct and indirect emissions of fertilizer use and animal husbandry. About $0.5-1 \mathrm{Tg} \mathrm{N} \mathrm{yr}^{-1}$ originates from the energy and industry sector, that is, the production of nitric and adipic acid and the transport sector.

$\mathrm{N}$ fertilizer use and animal husbandry are expected to continue to grow slowly in most scenarios. Scenarios by the IMAGE model, for instance, show typically a 50$100 \%$ increase in $\mathrm{N}$ fertilizer use and a $50-150 \%$ increase in livestock production during the 21st century [65-67]. By contrast, $\mathrm{N}_{2} \mathrm{O}$ emission from industrial sources are expected to decline significantly, as it is relatively easy to control these emissions in case of climate policy; in fact, important reductions have already been achieved in the past decades in different parts of the world [68]. Emissions from transport are relatively small - and thus has only a small impact on overall $\mathrm{N}_{2} \mathrm{O}$ emissions, although they have been slowly increasing with the introduction of catalytic converters. Future $\mathrm{N}_{2} \mathrm{O}$ emissions will thus depend on future agricultural production and practices and climate policy. Key agricultural factors include the

\section{Figure 3}

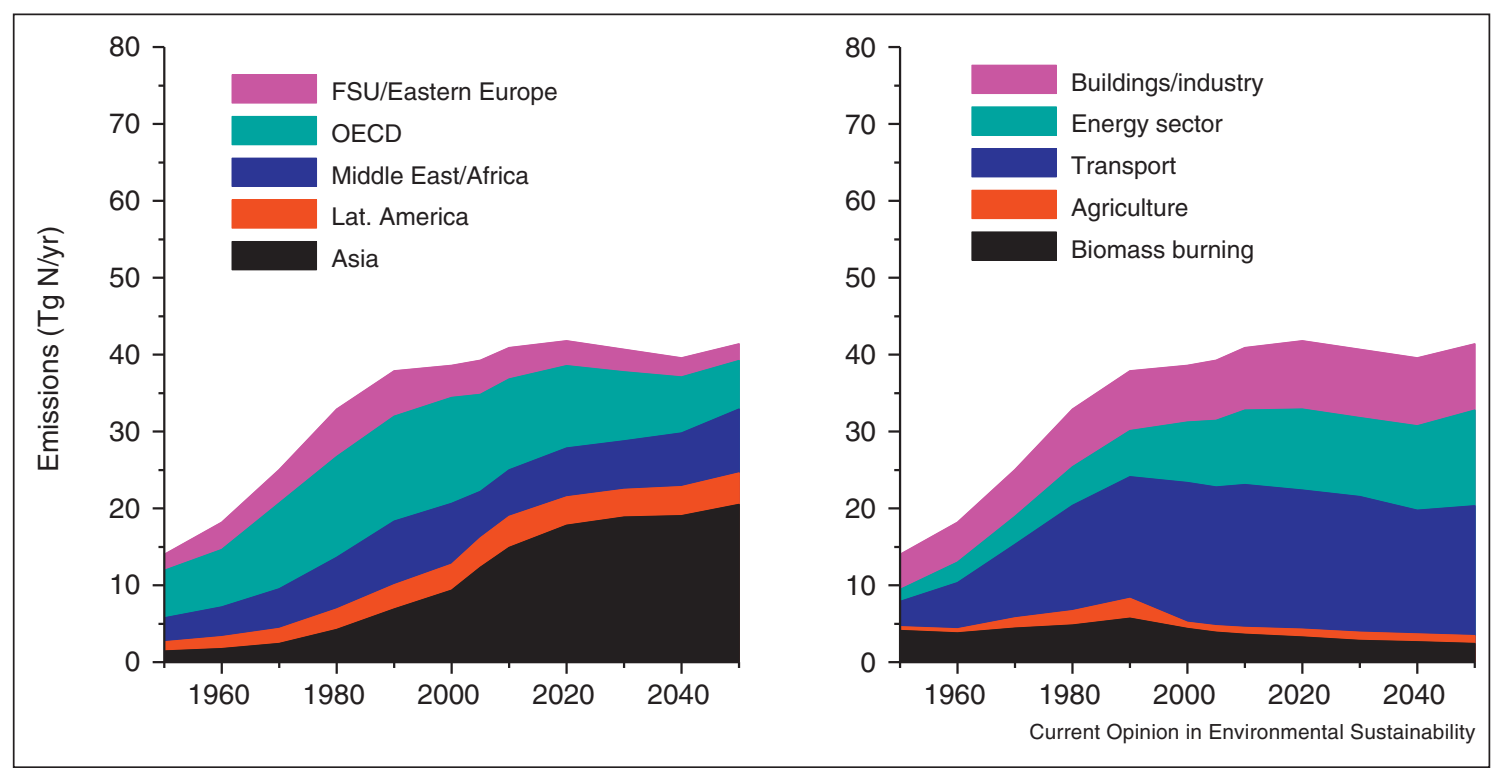

$\mathrm{NO}_{x}$ emissions according to the IMAGE reference scenario as published by van Vuuren et al. [56]. 


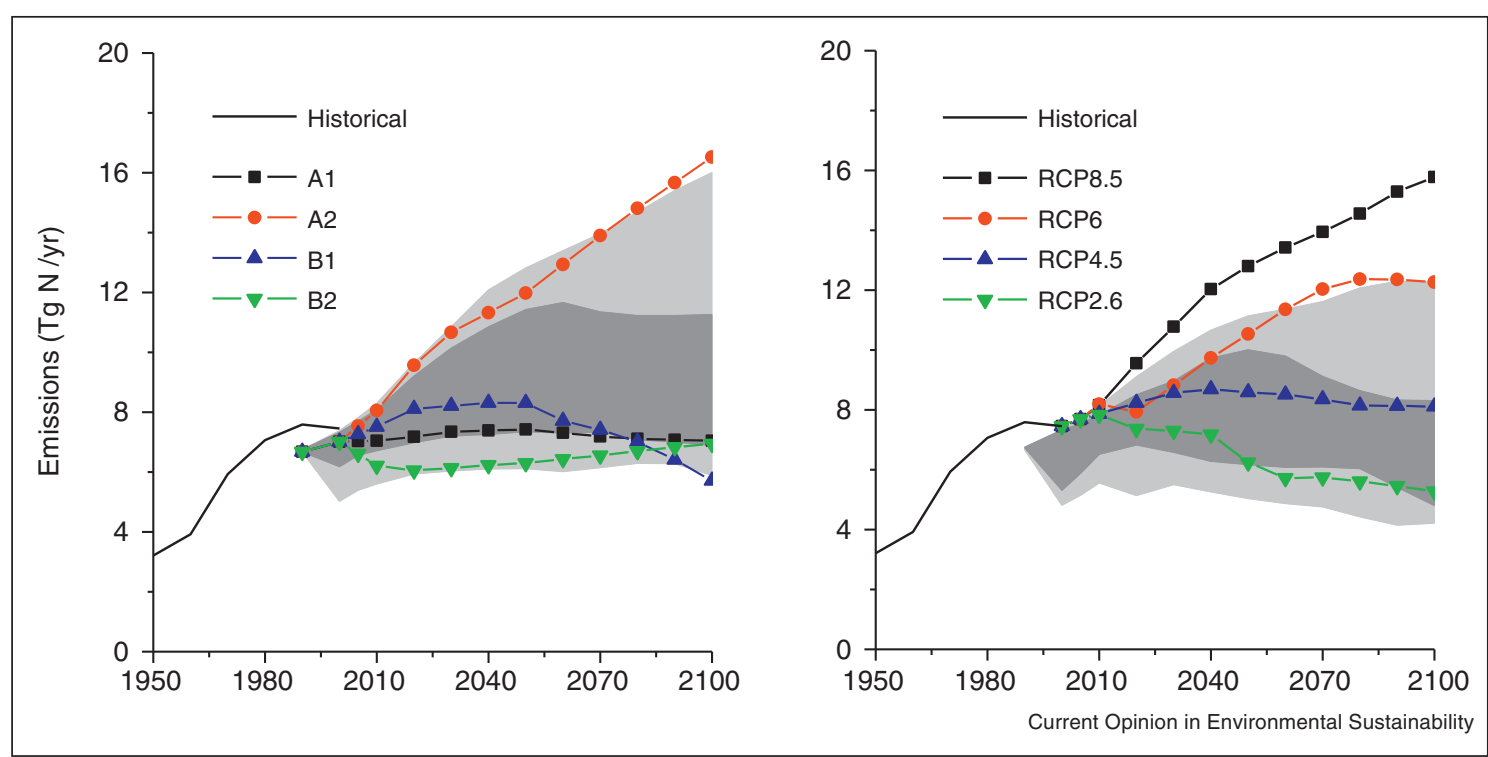

Future $\mathrm{N}_{2} \mathrm{O}$ emissions according to various scenarios (light grey area covers the 10-90th percentile; dark grey area the 25-75th percentile). The right hand panel only includes scenarios without climate policy; the left hand panel includes the full set of scenarios (with and without climate policy). In addition, the graph shows the scenarios of the IPCC-SRES set and the RCPs (including climate policy) (sources see Figure 1).

shifts in dietary patterns (the degree of meat consumption) and fertilizer application [67].

Figure 4 shows the range of scenarios from literature. In the absence of climate policy, most scenarios expect $\mathrm{N}_{2} \mathrm{O}$ emissions to increase somewhat (around $0-40 \%$ ) in the 2000-2050 period followed by stabilization (partly as result of a stabilizing global population). Some scenarios, however, indicate a further rapid increase in $\mathrm{N}_{2} \mathrm{O}$ emissions after 2050 (such as the IPCC A2 scenario, that projects a further population increase after 2050 [44]).

These results indicate that growth rates of $\mathrm{N}_{2} \mathrm{O}$ emissions without climate policy are not very different from those of the underlying economic factors while scenarios for $\mathrm{NO}_{x}$ show a reduction of the emission factors owing to other factors than climate policy, this is a less important factor for future $\mathrm{N}_{2} \mathrm{O}$ emissions, although some changes will occur owing to changes in underlying practices. Improved knowledge of the spatial and temporal dependency of emission factors, especially in the tropics, may further refine future scenarios.

If climate policy is included, the upper end of the literature range decreases, since $\mathrm{N}_{2} \mathrm{O}$ is directly targeted by climate policy. This is illustrated by the set of Representative Concentration Pathways that have the lowest $\mathrm{N}_{2} \mathrm{O}$ emission for the most stringent climate policy scenarios. Emissions are reduced by about $30 \%$ in the RCP2.6 scenario compared to 2000 as a result of emission reduction measures, such as improved manure management systems $\left[47^{\bullet \bullet}, 68\right]$.
Further emission reduction is limited by the fact that only a limited mitigation potential has been identified for $\mathrm{N}$ fertilizer use and animal husbandry [68]. This is partly related to the $\mathrm{N}$ cascade effect $\left[69^{\circ}\right]$, where a reduction in one part of the cascade (e.g. ammonia emissions from stored animal manure) may cause an increased emissioms in another part $\left(\mathrm{N}_{2} \mathrm{O}\right.$ emissions from manure spreading) [70]. An important aspect here is the recovery efficiency of $\mathrm{N}$ in food production, which determines the inputs of $\mathrm{N}$ fertilizer and animal manure in agricultural systems and the environmental losses (Figure 5). Especially in livestock production, recovery efficiencies are inherently low and can only be significantly increased by a shift from ruminant to white meat production $\left[50^{\circ}\right]$. Such projections are based on possible future technology development and improving management practices, which is a difficult task, particularly for low-income countries. Recovery efficiencies of $60-70 \%$ as currently achieved in some industrialized countries seem to be the maximum that can be achieved in practice, based on current knowledge and technology [71]. It should be noted that these recoveries refer to the production process only. The $\mathrm{N}$ that is finally consumed as food is much less $\left[69^{\circ}\right]$.

In some cases, climate policy may actually increase $\mathrm{N}_{2} \mathrm{O}$ emissions. For instance, both catalytic converters in cars and manure injections may increase $\mathrm{N}_{2} \mathrm{O}$ emissions. A potentially more important factor is that $\mathrm{N}_{2} \mathrm{O}$ emissions may increase as a result of the use of fertilizer in the production of bio-energy [72,73]. For first generation biofuel crops, the increase in $\mathrm{N}_{2} \mathrm{O}$ emissions alone may offset the gains of using bio-energy. 


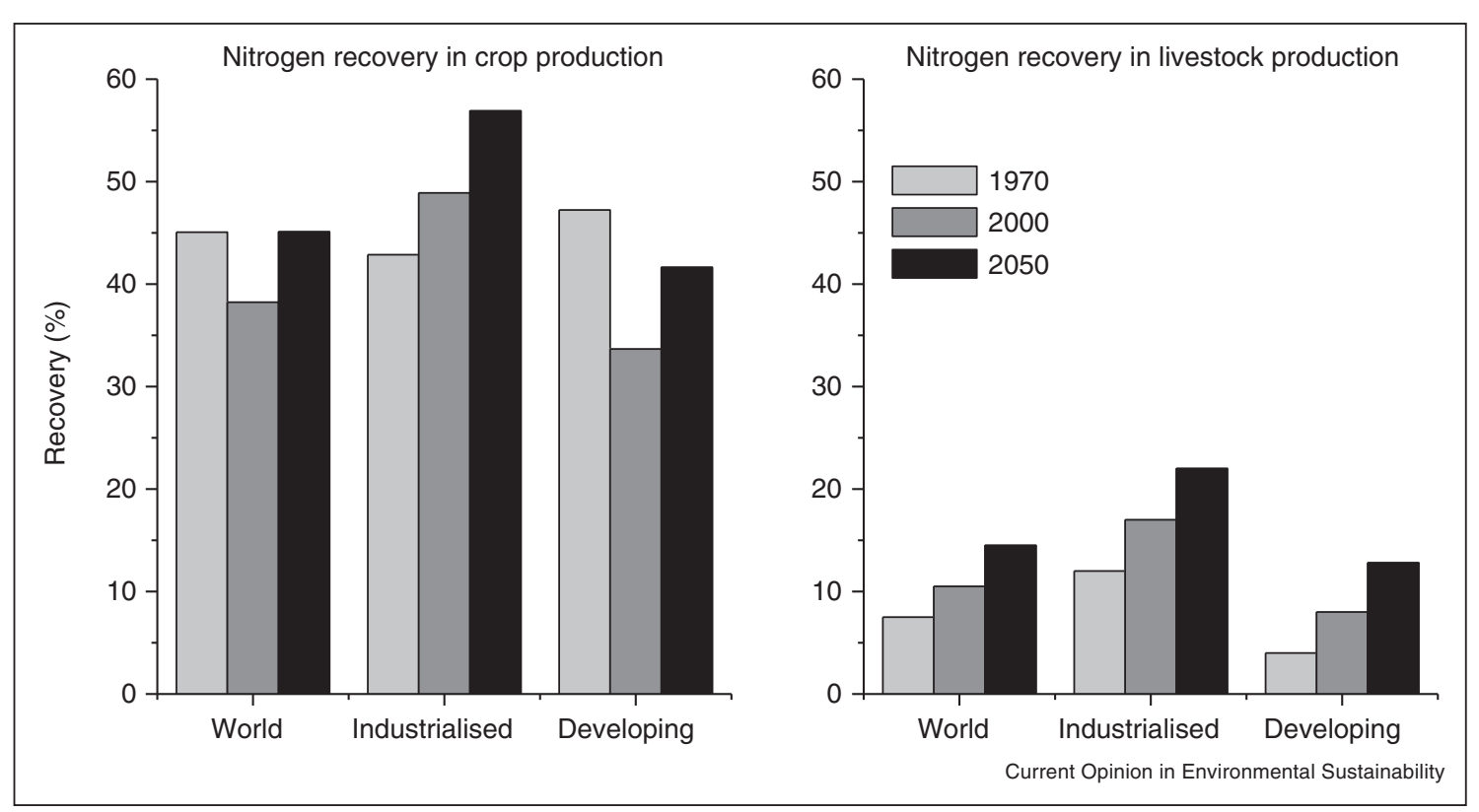

Global recovery of $\mathrm{N}$ in crop and livestock production for 1970, 2000 and 2050 in industrialized and developing countries (IMAGE scenario for the International Assessment of Agricultural Science and Technology Development, [3]). Recovery is calculated as the $\mathrm{N}$ in the harvested parts divided by the input of fertilizer and manure (crops) or feed (livestock).

\section{Projections for $\mathrm{NH}_{3}$}

$\mathrm{NH}_{3}$ emissions in 2000 amount to nearly $40 \mathrm{Tg} \mathrm{N} \mathrm{yr}^{-1}$. Most of these emissions originate from agricultural activities, that is, around $30 \mathrm{Tg} \mathrm{yr}^{-1}$, mostly from animal husbandry [55\%. About $10 \mathrm{Tg} \mathrm{yr}^{-1}$ come from biomass burning (land use change and savanna burning). A minor part stems from traffic, an unwanted side-effect of threeway catalytic converters in, particularly, light-duty gasoline vehicles, contributing about $5 \%$ of total $\mathrm{NH}_{3}$ emissions in the U.S.A. [74].

Expected growth of livestock production will lead to an increase of $\mathrm{NH}_{3}$ emissions, while biomass burning is not expected to increase significantly in the future; in fact, emissions from biomass burning may even decrease as a result from slowing deforestation [75] (either autonomously or as a result of, for instance, measures in the context of climate policy). In other words, trends in future $\mathrm{NH}_{3}$ emission mostly depend on agricultural practices and any measures that are introduced to decrease $\mathrm{NH}_{3}$ emissions.

Not many scenarios deal with future $\mathrm{NH}_{3}$ emissions. Dentener et al. $\left[7^{\circ}\right]$ present a global scenario on the basis of the implementation of the SRES scenarios by the IMAGE model, showing an increase in the order of $40-50 \%$. In the literature used for this paper, only the RCPs provide information of global trends in $\mathrm{NH}_{3}$ emissions. Here, both the underlying baseline scenarios and the
RCPs themselves were assessed to compile the literature range. The set shows (as expected) that very little relationship exists between climate policy and $\mathrm{NH}_{3}$ emissions, because $\mathrm{NH}_{3}$ is not directly targeted by climate policy (Figure 6).

Figure 6

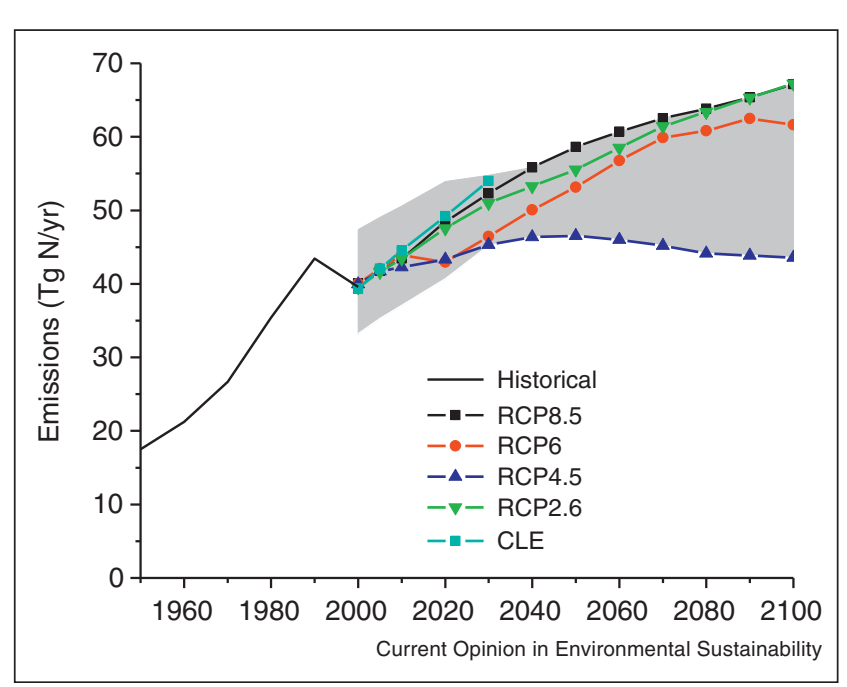

Future $\mathrm{NH}_{3}$ emissions according to various scenarios (light grey area covers the 10-90th percentile; dark grey area the 25-75th percentile).Source: CLE [26] and RCP scenarios and the underlying baselines [40]). 
We note that that the set of four scenarios does not cover the full uncertainty range. Long-term projections of $\mathrm{NH}_{3}$ emissions have only recently been constructed. For $\mathrm{NH}_{3}$ from agriculture, the major global source, both the $\mathrm{N}$ recovery (see above) and the nutrient management in agricultural systems are important. Thus, the use and management of both $\mathrm{N}$ fertilizers and animal manure play a key role in $\mathrm{NH}_{3}$ emissions [76]. Furthermore, there is a difference between systems dominated by grazing versus those where animals are confined. In the latter systems N can be lost from manure management systems, and also after spreading of stored manure in the field (the abovementioned $\mathrm{N}$ cascade $\left[69^{\circ}\right]$ ). In scenarios this aspect is not always considered, but is crucial because $\mathrm{NH}_{3}$ emission from intensive systems may exceed those from pastoral systems $\left[50^{\circ}\right]$. These emissions will also depend on the structure of future food demand, such as the consumption of meat from ruminants as compared to poultry.

\section{Conclusions}

Most scenarios containing information on future $\mathrm{Nr}$ gas emissions to the atmosphere imply that these emissions will slowly increase in the coming decades, followed by stabilization or decline. The $\mathrm{Nr}$ gas emissions have increased globally by about $150 \%$ in the $1950-2000$ period. The assessment of scenarios published in the literature suggests that emissions may further increase in the 2000-2050 period, but at a much slower rate than in past. The $50 \%$ percentile of scenarios with and without climate policy ranges from about -5 to $+35 \%$ increase compared to 2000. After 2050, emissions in most scenarios stabilize (scenarios without climate policy) or decline (scenarios with climate policy) leading to an overall range for the $50 \%$ percentile of $-25 \%$ to $+30 \%$ in 2100 compared 2000 (scenarios with and without climate policy).

Crucial factors that determine total future $\mathrm{Nr}$ emissions include the stringency of air pollution control measures in developing countries, agricultural development and future climate policy. The economic activities that drive $\mathrm{Nr}$ emissions are expected to continue to grow. This is especially the case for $\mathrm{NO}_{x}$, which mostly originates from electric power production and transport (scenarios show growth rates for these activities in the order of 60 up to $300 \%$ in 2000-2050 period). $\mathrm{N}_{2} \mathrm{O}$ emissions and $\mathrm{NH}_{3}$ emissions are dominated by animal husbandry and $\mathrm{N}$ fertilizer use, activities which are expected to have lower growth rates (in the order of $50 \%$ ). $\mathrm{Nr}$ emissions are not expected to grow at the same rate as the economic drivers: emission factors are expected to decline as a result of policy and structural changes. This is especially important for $\mathrm{NO}_{x}$ where at the global scale, declining emission factors alone may reduce emissions by up to $60 \% \mathrm{com}$ pared to the situation where emission factors would remain constant (but these depend on scenario assumptions). As $\mathrm{N}_{2} \mathrm{O}$ and $\mathrm{NH}_{3}$ emissions strongly depend on agricultural activities, the development of the agricultural sector also is a key factor determining future emission growth (e.g. agricultural policies or the dietary shifts towards animal products). A third factor of crucial importance to both $\mathrm{NO}_{x}$ and $\mathrm{N}_{2} \mathrm{O}$ emission is the introduction of climate policy. Such policies will directly (climate policies are likely to target $\mathrm{N}_{2} \mathrm{O}$ emissions) or indirectly $\left(\mathrm{NO}_{x}\right.$ emissions are influenced by the induced changes in the energy system) lead to emission reductions in most cases. However, some strategies may lead to increasing $\mathrm{N}_{2} \mathrm{O}$ emissions, such as bio-energy production (to reduce $\mathrm{CO}_{2}$ emissions) and strategies in animal manure management systems owing to the $\mathrm{N}$ cascade effect.

For making projections of future $\mathrm{Nr}$ gas emissions from agriculture, the most important tasks are to assess future recovery efficiencies of $\mathrm{Nr}$ in crop and livestock production systems, and to consider $\mathrm{N}$ cascade effects. Recovery efficiencies in livestock production are inherently low; changes in the share of ruminants versus that of pork and poultry appear to be more important for future $\mathrm{Nr}$ gas emissions than any management strategy. Recovery efficiencies in crop production are more readily increased, although in practice recoveries of $60-70 \%$ seem to be the maximum achievable. For $\mathrm{NH}_{3}$ and $\mathrm{N}_{2} \mathrm{O}$ projections, the $\mathrm{N}$ cascade involved in future development of intensive or industrial production systems of ruminants, and manure management systems is an important feature, which is often ignored in scenarios.

RCPs do not fully cover the range of possible futures. The representative emission scenarios (RCPs) were developed to explore climate change futures with and without stringent climate policy. Given their purpose, the RCPs are representative of the range of different emission trajectories for greenhouse gases (as shown here for $\mathrm{N}_{2} \mathrm{O}$ ). The scenarios also include a detailed set of emissions for air pollutants, given the role of these gases in climate change forcing. The overview here shows that the RCPs are not representative, however, of the full range of emissions scenarios of $\mathrm{NO}_{x}$ in the literature: the RCPs cover the low to medium range of the literature, while high emission scenarios are not well represented (on both sides the true uncertainty range might be even larger than suggested in our literature review). For the purpose of assessment of the impact of different air pollution control strategies it might therefore be useful to consider a wider range of scenarios. For $\mathrm{NH}_{3}$, present-day emission inventories are more uncertain than for $\mathrm{NO}_{x}$, In addition, an assessment of a full range of future $\mathrm{NH}_{3}$ emissions could not be made as a result of a lack of independently published scenarios.

\section{Acknowledgement}

The contribution of Detlef van Vuuren and Frank Dentener to this paper was supported by the PEGASOS project funded by the European Commission. 


\section{References and recommended reading}

Papers of particular interest, published within the period of review, have been highlighted as:

- of special interest

$\bullet$ of outstanding interest

1. MA: Our Human Planet: Summary for Decision Makers. Washington, DC: Island Press; 2005.

2. UNEP: Global Environment Outlook 4. Nairobi: UNEP; 2007.

3. Watson B (Ed): International Assessment of Agricultural Science and Technology Development. 2008.

4. Rockström J, Steffen W, Noone K, Persson Ã, Chapin FS, Lambin EF, Lenton TM, Scheffer M, Folke C, Schellnhuber HJ et al.: A safe operating space for humanity. Nature 2009 , 461:472-475.

5. Vitousek PM, Aber JD, Howarth RW, Likens GE, Matson PA, Schindler DW, Schlesinger WH, Tilman DG: Human alteration of the global nitrogen cycle: sources and consequences. Ecological Applications 1997, 7:737-750.

6. Galloway JN: The global nitrogen cycle: changes and consequences. Environmental Pollution 1998, 102:15-24.

7. Dentener F, Drevet J, Lamarque JF, Bey I, Eickhout B, Fiore AM,

- Hauglustaine D, Horowitz LW, Krol M, Kulshrestha UC et al.: Nitrogen and sulphur deposition on regional and global scales: a multi-model evaluation. Global Biogeochemical Cycles 2006, 20:GB4003 doi:4010.1029/2005GB002672.

Authors compare model results of 23 atmospheric chemistry transport models for 3 global scenarios.

8. Galloway JN, Townsend AR, Erisman JW, Bekunda M, Cai Z,

- Freney JR, Martinelli LA, Seitzinger SP, Sutton MA: Transformation of the Nitrogen cycle: recent trends, questions, and potential solutions. Science 2008, 320 889-892.

Authors discuss relevant aspects of the disturbance of $\mathrm{N}$-cycle - and proposes potential responses (including the need for a more integrated approach).

9. Gruber N, Galloway JN: An Earth-system perspective of the - global nitrogen cycle. Nature 2008, 451:293-296.

Authors show that nitrogen plays a critical role in other earth system problems such as disturbance of the carbon cycle.

10. Bouwman L, van Vuuren DP, Derwent RG, Posch M: Global assessment of acidification and eutrophication of natural ecosystems. Water Air and Soil Pollution 2002, 141:349-382.

11. Bobbink R, Hornung M, Roelofs JGM: The effects of air-borne nitrogen pollutants on species diversity in natural and semi-natural European vegetation. Journal of Ecology 1998, 86:717-738.

12. Galloway JN, Cowling EB: Nitrogen and the world. Ambio 2002, 31:64-71.

13. Bobbink R, Hicks K, Galloway J, Spranger T, Alkemade R, Ashmore M, Bustamante M, Cinderby S, Davidson E, Dentener F et al.: Global assessment of nitrogen deposition effects on terrestrial plant diversity: a synthesis. Ecological Applications 2010, 20:30-59.

14. Holland EA, Braswell BH, Lamarque JF, Townsend A Sulzman J, Müller J-F, Dentener F, Brasseur G, Levy H, JE P: Variations in the predicted spatial distribution of atmospheric nitrogen deposition and their impact on carbon uptake by terrestrial ecosystems. Journal of Geophysical Research 1997, 102:15849-15866.

15. Xu-Ri ICP: Terrestrial nitrogen cycle simulation with a dynamic global vegetation model. Global Change Biology 2008, 14:1745-1764.

16. Olivier JGJ, Van Aardenne JA, Dentener F, Pagliari V, Ganzeveld LN, Peters JAHW: Recent trends in global greenhouse gas emissions: regional trends and spatial distribution of key sources. Environmental Sciences 2005, 2:81-100.
17. IPCC: Climate Change The Scientific Basis. Cambridge University Press; 2007.

18. Lee DS, Grobler E, Rohrer F, Sausen R, Gallardo-Klenner L, Olivier JGJ, Dentener FJ, Bouwman AF: Estimations of global NOx emissions and their uncertainties. Atmospheric Environment 1997, 31:1735-1749.

19. Bouwman AF, Van der Hoek KW, Olivier JGJ: Uncertainties in the global source distribution of nitrous oxide. Journal of Geophysical Research 1995, 100:2785-2800.

20. Bouwman AF, Lee DS, Asman WAH, Dentener FJ, Van der Hoek KW, Olivier JGJ: A global high-resolution emission inventory for ammonia. Global Biogeochemical Cycles 1997, 11:561-587.

21. Clarke L, Edmonds J, Krey V, Richels R, Rose S, Tavoni M: International climate policy architectures: overview of the EMF 22 international scenarios. Energy Economics 2010, 31(Suppl. 2):S64-S81.

22. Weyant JP, de la Chesnaye FC, Blanford GJ: Overview of EMF21: Multigas Mitigation and Climate Policy. The Energy Journal 2007, Special issue \#3:1-32.

23. Van Vuuren DP, Weyant $J$, de la Chesnaye F: Multi-gas scenarios to stabilize radiative forcing. Energy Economics 2006, 28:102-120.

24. Granier C, Bessagnet B, Bond T, D'Angiola A, van der Gon HG, Frost G, Heil A, Kainuma M, Kaiser J, Kinne S et al:: Evolution of anthropogenic and biomass burning emissions at global and regional scales during the 1980-2010 period. Climatic Change 2011 doi: $10.1007 / \mathrm{s} 10584-011-0154-1$.

25. Alcamo J, Shaw R, Hordijk L: The RAINS Model of Acidification. Science and Strategies in Europe. Dordrecht, The Netherlands: Kluwer Academic Publishers; 1990.

26. Amann M, Cofala J, Heyes C, Klimont Z, Schöpp W: The RAINS model: a tool for assessing regional emission control strategies in Europe. Pollution Atmospherique 1999:41-63.

27. Posch M, Hettelingh JP, Alcamo J, Krol M: Integrated scenarios of acidification and climate change in Asia and Europe. Global Environmental Change - Human and Policy Dimensions 1996, 6:375-394.

28. Klimont Z, Cofala J, Xing J, Wei W, Zhang C, Kejun J, Bhandari P, Mathur R, Purohit P, Rafaj P et al.: Projections of SO2, NOx and carbonaceous aerosol emissions in Asia. Tellus 2009 61B:602-8617.

29. Cofala J, Amann M, Asman WAH, Bertok I, Heyes C, Hoeglund Isaksson L, Klimont Z, Schoepp W, Wagner F: Integrated assessment of air pollution and greenhouse gases mitigation in Europe. Archives of Environmental Protection 2010, 36:29-39.

30. Cofala J, Amann M, Klimont Z, Kupiainen K, Höglund-Isaksson L: Scenarios of global antropogenic emissions of air pollutants and methane until 2030. Atmospheric Environment 2007, 41:8468-8499.

31. Van Harmelen T, Bakker J, de Vries B, van Vuuren DP, den Elzen MGJ, Mayerhofen P: An analysis of the costs and benefits of joint policies to mitigate climate change and regional air pollution in Europe. Environmental Science and Policy 2002, 5:349-365.

32. Stern DI: The Environmental Kuznets Curve - http:// www.ecoeco.org/pdf/stern.pdf).\&\#32. In International Society for Ecological Economics Internet Encyclopedia of Ecological Economics; 2003.

33. Smith SJ: Income and pollutant emissions in the ObjECTS MiniCAM Model. Journal of Environment and Development 2005, 14:175-196.

34. Riahi K, Grübler A, Nakicenovic N: Scenarios of long-term socioeconomic and environmental development under climate stabilization. Technological Forecasting and Social Change 2007, 74:887-935.

35. van Ruijven B, Urban F, Benders RMJ, Moll HC, van der Sluijs JP, de Vries B, van Vuuren DP: Modeling energy and development: an evaluation of models and concepts. World Development 2008, 36:2801-2821. 
36. Stern D: Reversal of the trend in global anthropogenic sulfur emissions. Global Environmental Change 2006, 16:207-220.

37. Bouwman AF, Boumans LJM, Batjes NH: Modeling global annual $\mathrm{N} 2 \mathrm{O}$ and NO emissions from fertilized fields. Global Biogeochemical Cycles 2002, 16:1080 doi:1010.1029/ 2001GB001812.

38. Freibauer A: Regionalised inventory of biogenic greenhouse gas emissions from European Agriculture. European Jouirnal of Agronomy 2003, 19:135-160.

39. Li C, Aber J: A process-oriented model of N2O and NO emissions from forest soils: I. Model development. Journal of Geophysical Research 2000, 105:4369-4384.

40. Del Grosso SJ, Ojima DS, Parton WJ, Stehfest E, Heistemann M, Deangelo B, Rose S: Global scale DAYCENT model analysis of greenhouse gas emissions and mitigation strategies for cropped soils. Global and Planetary Change 2009, 67:44-50.

41. Carpenter S, Pingali P: Millennium Ecosystem Assessment Scenarios Assessment. Washington, DC: Island Press; 2005.

42. Van Vuuren DP, Den Elzen MGJ, Lucas PL, Eickhout B, Strengers BJ, Van Ruijven B, Wonink S, Van Houdt R: Stabilizing greenhouse gas concentrations at low levels: an assessment of reduction strategies and costs. Climatic Change 2007, 81:119-159.

43. Isaksen I, Granier C, Myhre G, Berntsen T, Dalsoren S, Gauss M, Klimont Z, Benestad R, Bousquet P, Collins W et al:: Atmospheric composition change: climate-chemistry interactions. Atmospheric Environment 2009, 43:5138-5192.

44. Nakicenovic N: Global greenhouse gas emissions scenarios: integrated modeling approaches. Technological Forecasting and Social Change 2000, 63:105-109.

45. Van Vuuren DP, Meinshausen M, Plattner GK, Joos F,

- $\quad$ Strassmann KM, Smith SJ, Wigley TML, Raper SCB, Riahi K, De La Chesnaye $\mathrm{F}$ et al:: Temperature increase of 21st century mitigation scenarios. In Proceedings of the National Academy of Sciences of the United States of America 2008, 105:15258-15262.

Overview of climate consequences of a wide range of scenarios, that also include $\mathrm{N}_{2} \mathrm{O}$ and $\mathrm{NO}_{x}$ emissions.

46. Moss RH, Edmonds JA, Hibbard KA, Manning MR, Rose SK, van Vuuren DP, Carter TR, Emori S, Kainuma M, Kram T et al.: The next generation of scenarios for climate change research and assessment. Nature 2010, 463:747-756.

47. Van Vuuren DP, Edmonds J, Thomson A, Riahi K, Kainuma M,

- Matsui T, Hurtt GC, Lamarque J-F, Meinshausen M, Smith S et al. Representative concentration pathways: an overview. Climatic Change 2011 doi: 10.1007/s10584-011-0148-z.

Recently developed set of scenarios that will be used in climate research These scenarios include a detailed description of greenhouse gas and air pollutant emissions.

48. Alcamo J, Van Vuuren DP, Cramer W: Change in ecosystem services and their drivers across the scenarios. In Ecosystems and Human Well-being. Scenarios, vol 2. Edited by Carpenter SR, Pingali P, Bennett EM, Zurek MB. Island Press; 2005.

49. Bouwman AF, Beusen AHW, Billen G: Human alteration of the

- global nitrogen and phosphorus soil balances for the period 1970-2050. Global Biogeochemical Cycles 2009, 23: doi: 10.1029/ 2009GB003576.

Authors present a set scenarios for the $\mathrm{N}$ and $\mathrm{P}$ soil balances on the basis of the scenarios from the Millennium Ecosystem Assessment.

50. Bouwman AF, Klein Goldewijk K, Van der Hoek KW, Beusen AHW,

- Van Vuuren DP, Willems WJ, Rufino MC, Stehfest E: Exploring global changes in nitrogen and phosphorus cycles in agriculture, induced by livestock production, over the 1900 2050 period. Proceedings of the National Academy of Sciences of the United States (PNAS) 2011, doi:10.1073/pnas.1012878108.

Comprehensive spatially explicit analysis of $\mathrm{N}$ and $\mathrm{P}$ surpluses over the 1900-2000 period, including scenario analysis for 2050. The study also looks into various options to reduce $\mathrm{N}$ and $\mathrm{P}$ emissions.

51. Bouwman AF, Kram T, Klein Goldewijk K (Eds): Integrated Modelling of Global Environmental Change. An Overview of IMAGE
2.4. Bilthoven: Publication 500110002/2006, Netherlands Environmental Assessment Agency; 2006.

52. Garg A, Shukla PR, Bhattacharya S, Dadhwal VK: Subregion (district) ans sector level SO2 and NOx emissions for India: assessment of inventories amd mitigation flexibility. Atmospheric Environment 2001, 35:703-713.

53. EC-JRC/PBL: Emission Database for Global Atmospheric Research (EDGAR), release version 4.0. http://edgar.jrc.ec europa.eu. Edited by: European Commission, Joint Research Centre (JRC)/Netherlands Environmental Assessment Agency (PBL); 2009.

54. Schultz M, Rast S, van het Bolscher M, Pulles T, Pereira J, Spessa A, Dalsøren S, van Nojie T, Szopa S: REanalysis of the TROpospheric chemical composition over the past 40 years, $A$ long-term global modeling study of tropospheric chemistry funded under the 5th EU framework programme. EU-Contract No. EVK2-CT-2002-00170. Edited by: http://www.retro.enes.org/ reports/D1-6final.pdf; 2007.

55. Lamarque J-F, Bond TC, Eyring V, Granier C, Heil A, Klimont Z,

- Lee D, Liousse C, Mieville A, Owen B et al.: Historical (1850-2000) gridded anthropogenic and biomass burning emissions of reactive gases and aerosols: methodology and application. Atmospheric Chemistry and Physics Discussions 2010, 10:4963-5019.

Authors of this study describe a detailed emission inventory used to support the development of new scenarios for climate research. The inventory is also used to calculate changes in air pollution.

56. Klimont Z, Streets DG: Emissions inventories and projections for assessing hemispheric or intercontinental transport. In Hemispheric Transport of Air Pollution. Edited by Keating T, Zuber A. United Nations; 2007.

57. Yohe GW, Montgomery D, Balistreri EU-hwscsaBV-FD-bdceed: Equity and the Kyoto Protocol: measuring the distributional effects of alternative emissions trading regimes. Global Environmental Change 2000, 10:121-132.

58. Schöpp W, Klimont Z, Suutari R, Cofala J: Uncertainty analysis of emission estimates in the RAINS integrated assessment model. Environmental Science and Policy 2005, 8:601-613.

59. Beusen AHW, Bouwman AF, Heuberger PSC, Van Drecht G, Van Der Hoek KW: Bottom-up uncertainty estimates of global ammonia emissions from global agricultural production systems. Atmospheric Environment 2008, 42:6067-6077.

60. Clarke LE, Edmonds JA, Jacoby HD, Pitcher H, Reilly JM, Richels $\mathrm{R}$ : Scenarios of greenhouse gas emissions and atmospheric concentrations. Sub-report 2.1a of synthesis and assessment product 2.1. Washington, DC: Climate Change Science Program and the Subcommittee on Global Change Research; 2007.

61. Reilly JM, Paltsev S: The Role of non-CO2 greenhouse gases in climate policy: analysis using the MIT IGSM. Energy Journal 2006. Special issue.

62. Unger N, Shindell DT, Koch D, Amann M, Cofala J, Streets D: Influences of man-made emissions and climate changes on tropospheric ozone, methane and sulfate at 2030 from a broad range of possible futures. Journal of Geophysical Research 2006, 111:D12313 doi:12310.11029/12005JD006518.

63. Amann M: Baseline Scenarios for the Revision of the NEC Emission Ceilings Directive Part 1: Emissions Projections. Laxenbourg, Austria: International Institute for Applied System Analysis; 2006.

64. Ohara T, Akimoto H, Kurokawa J, Horii N, Yamaji K, Yan X, Hayasaka T: An Asian emission inventory of anthropogenic emission sources for the period 1980-2020. Atmospheric Chemistry and Physics and Chemistry of the Earth 2007, 7:4419-4444.

65. Alcamo J, van Vuuren D, Ringler C, Cramer W, Masui T, Alder J Schulze K: Changes in nature's balance sheet: model-based estimates of future worldwide ecosystem services. Ecology and Society 2005, 10:.

66. IMAGE-team: The IMAGE 2.2 implementation of the IPCC SRES scenarios. A comprehensive analysis of emissions, climate change and impacts in the 21st century. Bilthoven, the 
Netherlands: National Institute for Public Health and the Environment; 2001.

67. Bouwman AF, Klein Goldewijk K, Van der Hoek KW, Beusen AHW, Van Vuuren DP, Willems WJ, Rufino MC, Stehfest E: Exploring global changes in nitrogen and phosphorus cycles in agriculture, induced by livestock production, over the 1900 2050 period. In Proceedings of the National Academy of Sciences of the United States (PNAS) 2011. Available on-line.

68. Lucas PL, Van Vuuren DP, Olivier JGJ, Den Elzen MGJ: Long-term reduction potential of non- $\mathrm{CO} 2$ greenhouse gases. Environmental Science \& Policy 2007, 10:85-103.

69. Galloway JN, Aber JD, Erisman JW, Seitzinger S, Howarth RW, - Cowling EB, Cosby BJ: The nitrogen cascade. BioScience 2003, 53:341-356.

Paper introduces the notion of the nitrogen cascade to describe the multiple effects of reactive nitrogen in the atmosphere, terrestrial ecosystems and in water systems.

70. Velthof GL, Oudendag D, Witzke HP, Asman WAH, Klimont Z, Oenema $O$ : Integrated assessment of nitrogen losses from agriculture in EU-27 using MITERRA-EUROPE. Journal of Environmental Quality 2009, 38:402-417.

71. Giller KE, Chalk P, Dobermann A, Hammond L, Heffer P, Ladha JK, Nyamudeza P, Maene L, Ssali H, Freney J: Emerging technologies to increase the efficiency of use of fertilizer nitrogen. In Agriculture and the Nitrogen Cycle. Edited by Mosier AR, Syers JK, Freney JR. Island Press; 2004:35-51.

72. Smeets EMW, Bouwman LF, Stehfest E, van Vuuren DP, Posthuma A: Contribution of N2O to the greenhouse gas balance of first-generation biofuels. Global Change Biology 2009, 15:1-23.

73. Crutzen PJ, Mosier AR, Smith KA, Winiwarter $\mathrm{W}$ : N2O release from agro-biofuel production negates global warming reduction by replacing fossil fuels. Atmospheric Chemistry and Physics Discussions 2007, 7:11191-11205.

74. Kean AJ, Littlejohn D, Ban-Weiss GA, Harley RA, Kirchstetter TW, Lunden MM: Trends in on-road vehicle emissions of ammonia. Atmospheric Environment 2009, 43:1565-1570.

75. Smith P, Gregory PJ, Van Vuuren D, Obersteiner M, Havlík P Rounsevell M, Woods J, Stehfest E, Bellarby J: Competition for land. Philosophical Transactions of the Royal Society B: Biological Sciences 2010, 365:2941-2957.

76. Bouwman AF, Boumans LJM, Batjes NH: Estimation of global NH3 volatilization loss from synthetic fertilizers and animal manure applied to arable lands and grasslands. Global Biogeochemical Cycles 2002, 16:1024 doi:1010.1029/ 2000 GB001389. 